\title{
The global ambitions of Irish universities: internationalizing practices and emerging stratification in the Irish higher education sector.
}

\section{Aline Courtois}

\section{Introduction}

The internationalization of higher education has become a policy imperative in many countries (Altbach 2007). It is closely connected with national and regional economic objectives (Ball 2012) and leads national university systems, and individual universities within national fields, to compete with each other (Hazelkorn 2015). Internationalization can be understood as the process by which universities respond to the convergent forces of marketization and economic globalization (Rizvi and Lingard 2010). Yet universities are complex organizations which, unlike others, manage multiple and competing obligations and cannot operate purely according to market principles (Marginson 2013). While they may be actors and drivers of internationalization to some extent (Matus and Talburt 2009), they remain tied to the state and are constrained by external factors such as national economic or immigration policy. Arguably, all universities (or at least all research universities) are subject to the same forces and expected to compete on the same global market. In this sense, internationalization may act as a homogenizing force, potentially reinforcing institutional isomorphism (DiMaggio and Powell 1983). In addition, the impact of globalization on universities varies from one national context to another (Currie et al. 2003; Rivzi and Lingard 2010) and from one institution to another: external forces are mediated differently by universities because their internal characteristics influence their capacity to strategize (Bartell 2003; Mosneaga and Agergaad 2012; Paradeise and Thoenig 2015). In terms of impact, while the 'world-class' status may be desirable for all (Salmi 2009), some universities manage to position themselves on an international elite market, others on a commercial mass market, while many fall back on the domestic market (Marginson 2006).

In sum, the structure, institutional culture and organizational identity of universities influence the shape of internationalization and its consequences, even where universities evolve in a relatively homogeneous policy context within national boundaries. Universities operate in fields, namely social arenas, in which interdependent agents vie for positions (Bourdieu 1996; Fligstein and McAdam 2012) and are driven by common institutional practices (DiMaggio and Powell 1983). Under globalization, the national field of higher education is no longer isolated from extranational influences, it is also shaped by them (Marginson 2006). To better understand how internationalization impacts on the field of higher education, a shift in focus from policy-making and organizational adaptation to the microdynamics and their effects on actual practices is necessary (Enders 2012). This is illustrated by Cantwell and Maldonado-Maldonado's case studies, in which they examine internationalizing practices beyond the internationalization discourse (2009).

This chapter sets out to contribute to the ongoing discussion of isomorphism and differentiation in the context of globalizing higher education (Popp Berman and Paradeise 2016) by focusing on the case of Irish universities. It examines how internationalizing strategies and practices vary according to internal characteristics and forces; how universities, as agents, manage, mediate and produce 
internationalization; and in particular, how they utilize student mobility programs and partnerships to consolidate or improve their respective positions in the national field.

The basis of this examination is an analysis of national and institutional policies, statistical analysis of university partnerships and student mobility figures, and semi-structured interviews with international officers and academic coordinators $(\mathrm{N}=10)$ across six sites. ${ }^{1}$ It is supported by data collected as part of an ongoing project on international mobility among Irish students (under the NUI Dr Garret Fitzgerald Post-Doctoral Fellowship in the Social Sciences, 2014-2016), which includes a qualitative questionnaire $(\mathrm{N}=110)$ and interviews with students returning from exchange $(\mathrm{N}=22)$. Unlike other studies of internationalizing strategies (e.g. Mosneaga and Agergaard 2012), interview participants are not senior managers but individuals engaged in the groundwork of managing student mobility. This approach provides deeper insights into actual practices and effects and helps reveal the internal contradictions and constraints that emerge at the operational level.

The first section presents the Irish policy environment that shapes the overall approach to internationalization across higher education institutions (HEIs). The second section examines the status hierarchy of Irish HEIs in the national field. The third section asks how national policies are implemented at the institutional level and how this intersects with the status hierarchy differentiating HEIs. The final section examines the differential treatment of student mobility programs within institutions and its consequences on stratification within universities.

\section{Global ambitions: the national strategy for internationalization}

\section{Marketization and internationalization}

As elsewhere in Europe and beyond, Irish universities are struggling to adapt to combined global and local pressures (Popp Berman and Paradeise 2016). In Ireland, the most pressing issues include rising enrolment figures, falling state funding, and expectations of economic efficiency and global competitiveness. In particular, Exchequer funding of higher education was cut by 37 percent between 2008 and 2014 (IUA 2014), causing a severe funding crisis that accelerated casualization and diminished staff-student ratios across the board (Courtois and O'Keefe 2015). The broader economic crisis justified policies aimed at further aligning HEIs with national economic goals. Thus the National Strategy for Higher Education to 2030 (Hunt 2011) framed the mission of the sector principally in economic terms, deploying the vocabulary of employability, entrepreneurship and international competitiveness. It encouraged HEIs to become more financially autonomous by developing new funding streams and advocated greater government control, or 'steering', of universities in order to ensure their alignment with the national economic strategy (Harkin and Hazelkorn 2014). New public management methods have played a central role in the ongoing dual process of rationalization and marketization of the sector (Lynch 2013).

A separate strategic plan focuses specifically on internationalization. Investing in Global Relationships: Ireland's International Education Strategy 2010-2015 (DES 2010) frames higher education as "an important internationally traded service" (2010,

\footnotetext{
${ }^{1}$ In some sections, universities are designated not by name but by their status as "old" or "new" universities in order to protect the anonymity of respondents. For the same reason, their names and on occasion their gender have been changed.
} 
p. 31). International students are envisaged as economic units, estimated to contribute over $€ 1$ billion to higher education as well as other sectors of the Irish economy, for instance through fees paid to universities and private language schools, living expenses, and travel in Ireland (Education in Ireland 2012). Firstly, the main objective of internationalization, as laid out in this document, is to continue developing this revenue stream. While the government capped EU undergraduate fees at $€ 2750$ per year across all universities (approximately a quarter of the amount charged in the neighboring UK), there is no such limit on how much HEIs can charge non-EU students. They are constrained only by market forces - not by considerations of equality, which apply solely to the national sphere (see Tannock 2009). Secondly, internationalization is aimed at "promoting Ireland's international profile, forging strategic links with partners overseas ... and developing a new network of influence among Irish-educated alumni" (DES 2010, p. 31). It is conceived of as an instrument to support Ireland's position on the global economic market through the establishment of strategic international networks:

The most compelling rationale for internationalisation is investment in future global relationships: with students educated in Ireland who will become our advocates overseas . . . and with the countries that will be Ireland's next trading and business partners (DES 2010, p. $11)$.

The strategy involves the selection of students according to economic rather than egalitarian or developmental principles. A key strategic goal is to "identify and target" students who are "likely to become the next generation of leaders, entrepreneurs and decision-makers in countries of importance to Ireland" (2010, p. 57), namely future elites who will direct investment to Ireland. Students from countries selected according to "market intelligence" must be prioritized (2010, p. 37). These include in particular the high-growth economies of Asia and South America and the United States. ${ }^{2}$ The overarching objectives are thus revenue and future trade and business opportunities, which corresponds to an "imperialist" orientation toward internationalization (Foskett 2010) - even though the national imaginary of this small, post-colonial nation is aligned with non-imperial, benevolent values (Khoo 2011). This strategic document makes visible a willingness to harness the internationalization of HEIs to national economic and diplomatic objectives as defined by the state.

\section{Government steering and market intervention}

The state, and in particular the Department of Jobs, Enterprise and Innovation, is strongly involved in steering the internationalizing activities of HEIs. In 2014, the Higher Education Authority (HEA) established a series of performance agreements with each state-aided HEI. These agreements set binding targets, and institutions failing to achieve them incur funding penalties. Increasing the numbers of incoming fee-paying non-EU students features prominently in the "Mission-based Performance Compacts" signed by each university, with some institutions pledging to double their international recruitment over a two-year period.

\footnotetext{
${ }^{2}$ Given that Irish universities find themselves in a subordinate position on the global higher education market, it is unclear how this can be achieved, as more affluent mobile students are likely to continue choosing elite institutions in the UK and US.
} 
In 2013-14, between 10 and 14 percent of full-time university students were international students, ${ }^{3}$ while the objective set in 2010 for 2015 was 25 percent. Irish universities face a number of constraints, among them financial and capacity issues, as student numbers increase and state funding plummets. Immigration laws are also problematic. ${ }^{4}$ What is more, Ireland does not enjoy a dominant position on the global education market and attracts much lower numbers than the neighboring UK: Irish universities grew in the shadow of their more prestigious British counterparts and do not achieve high positions in rankings, partly due to decreased funding. Constraints linked to funding, capacity, competition and location make it difficult for Irish universities to become significant players on either the global positional market (dominated by elite US and UK universities) or the global mass market (dominated by less elite UK and Australian universities) (Marginson 2006). An additional constraint is the participation in intra-European mobility through Erasmus: the expectation of reciprocity at the core of the program (and the fact that Erasmus students do not contribute fees to their host university) runs counter to financial objectives. As elsewhere (e.g. Stensaker et al. 2008), there appears to be a significant disconnect between national policy-making and institutional needs.

Education In Ireland ("World-class standards, warmest of welcomes"), the brand launched under the remit of the Enterprise Ireland state agency, acts as a channel to recruit international students to all (including private for-profit) HEIs. Selected HEIs take part in state-subsidized marketing operations and promotional tours around the globe. In addition, the Irish government has negotiated Ireland's participation in mobility programs funded by the US and Brazilian governments. The Brazilian students in particular have been distributed between various HEIs, including peripheral ones. Thus the state interferes significantly in the education market, steering internationalization and assisting HEIs in their promotional and recruitment activities. This ensures a relatively high degree of conformity to the mission of higher education as set by the state. Frequent negotiations between the HEA and individual HEIs ensure that specific characteristics are taken into account and mutually agreed institutional objectives are tailored accordingly, while national objectives prevail.

\section{Elite universities? Principles of differentiation in the university sector}

Institutions mediate government policy in different ways. Their capacity to strategize is constrained by their respective institutional structures and locations in the national field. Ireland is a small country (4.5 million inhabitants), with seven multidisciplinary universities, 14 institutes of technology, a number of state-supported specialized third-level colleges and a flourishing private for-profit third-level sector. Unlike the situation in other jurisdictions, there are no distinct third-level elite institutions in Ireland; the educational backgrounds of political and business elites are relatively diverse (Courtois forthcoming), and at third level, elite educational spaces appear

\footnotetext{
${ }^{3}$ The low estimate is based on HEA figures and the high estimate on DES figures for the domiciliary origin of students.

${ }^{4}$ In 2014 , international students protested against the way they were treated by Irish immigration services, as visa renewals required overnight queuing. Non-EU students are barred from entering the Irish labour market after completing their education. In addition, immigration rules were tightened in 2015 following revelations that a number of for-profit English-language schools had been operating as "visa mills".
} 
diffuse, spread across various institutions and extending beyond national boundaries in particular to the neighboring UK. Yet, and in spite of its small size, the Irish higher education sector is differentiated and distinctly stratified. It operates as a "two-tiered system" (McCoy and Smyth 2011), in which universities are more selective and prestigious than other HEIs. The university sector is itself stratified: the seven universities are not equal in prestige. Among them, Trinity College Dublin (TCD) is perhaps the best known. Founded in 1592 to educate the local Protestant elite, it is the oldest HEI in Ireland. Its history of social and ethnic exclusivity (Catholics used to be excluded from it), its central city location and physical character contribute to its aura of prestige. University College Cork (UCC) and the National University of Ireland, Galway (NUIG), were established by Royal Charter in 1845 as "Queen's Colleges" together with Queen's University Belfast in Northern Ireland. The Catholic college which later became University College Dublin (UCD) was founded separately in 1854. It has since moved to a modern campus on the outskirts of the city and has grown to become the largest Irish university. TCD, UCD, UCC and NUIG were the only recognized universities in existence before the onset of massification in the 1970s, which differentiates them from more recent institutions, since, here as elsewhere, ancestry carries significant symbolic power (Paradeise and Thoenig 2015). For its part, Maynooth University (MU) officially acquired university status in 1997, but it has a history dating back to the late eighteenth century as an ecclesiastical college - a relatively long history still visible in the architecture of part of its campus.

Between 1967 and 1992, as theories of human capital channeled through the OECD were introduced to a country embarking on economic development, the number of third-level students more than quadrupled. Institutes of Technology largely absorbed the increased working-class participation (Clancy 2015). The University of Limerick (UL) and Dublin City University (DCU) were founded in the context of massification, in 1972 and 1975 respectively, as "Institutes of Higher Education" but were both elevated to university status in 1989 . Yet these new universities have not achieved the level of respectability of their elders. DCU in particular is still occasionally referred to as the "Tech," as if its relatively recent university status was somehow usurped. For its part, the Dublin Institute of Technology (DIT), originally focused on vocational education, is now offering research degrees and has been striving for university status for a number of years. As elsewhere (Teichler 2002/3), massification has led to vertical differentiation in terms of levels of qualification (with an 18.4 percent increase in postgraduate output over the 2007-2011 period alone [HEA 2012, p. 22]) as well as in terms of differentiated institutional status. Meanwhile, horizontal differentiation (namely between professional and nonprofessional education) is becoming secondary as the imperative of "excellence" and the hegemony of rankings lead all institutions to compete on the fields of research and postgraduate enrolments regardless of their original vocation. Nonetheless, the typological distinction between universities and other HEIs, and their foundation dates and history play a role in the status hierarchy symbolically ordering these institutions.

Another principle of differentiation is the degree of selectivity of HEIs. The grades obtained in the final second-level examinations are combined into a point score, which then determines students' chances of being admitted to their chosen course. High-point courses (requiring over 500 points) are considered "elite" and represent 6.8 percent of the total number of undergraduate courses on offer across the sector. Out of 96 such courses on offer for the academic year 2015-2016, 39 are located at TCD and a further 29 at UCD. By contrast, a less established university like 
UL only offers two such courses. ${ }^{5}$ Thus, while high point requirements are aligned with subject specializations (with law, medicine and select business and science courses emerging as elite courses), and while elite courses are not the preserve of one single institution, the symbolic economy of point requirements reflects the status hierarchy of HEIs.

In the 2015 Times Higher Education (THE) World University Ranking, TCD achieved position 138, making it the highest ranked Irish HEI, followed by UCD in the 226-250 bracket, NUIG (251-275) and UCC (276-300). For its part, DCU featured in the " 100 under 50 " category. MU and UL, while no longer included, celebrated their positions in the same ranking in 2014 and 2012 respectively (UL now boasts instead the highest rate of graduate employment). Roughly the same hierarchy (with UCC ahead of NUIG) is visible in the QS ranking. These rankings based on (supposedly) objective criteria thus replicate and formalize existing status hierarchies between institutions, ${ }^{6}$ with TCD and UCD at the top, UL and DCU at the bottom, and the other three universities in between. To some extent, this status hierarchy is reflected in the intake of international students: the proportion of international fulltime students is 16.7 percent at TCD, 15.1 percent at UCD, 18.4 percent at NUIG, 12.5 percent at UCC, 7.2 percent at MU, 10.4 percent at DCU and 6.9 percent at UL. ${ }^{7}$ This proportion is 6.2 percent at DIT (slightly higher than the 5.8 percent average over the institutes of technology sector), which indicates that, in spite of its relatively subordinate position on the national market, it is also a contender in the competition for international students. Although much smaller in size, and traditionally locally oriented, four other institutes of technology claim rates of international recruitment of over 8 percent. However, the centralized distribution of students recruited through programs negotiated at state level may partially account for these figures.

Nonetheless, they still suggest convergence in the way institutions have adapted to the "imperative" of internationalization.

\section{The implementation of internationalization by Irish universities}

\section{Differentiated market positions and strategies}

In terms of institutional identities among the "old" universities, TCD now positions itself as "Ireland's leading university" and UCD as "Ireland's global university"; more modestly, UCC calls itself "Ireland's five-star university", and NUIG is "among the top 2 percent of universities in the world." By contrast, the "new" universities describe themselves as "pioneering and connected" (UL), "young, dynamic and ambitious" (DCU), and "Ireland's fastest growing university" (MU).

Internationalization in Irish universities was "an ad-hoc and marginal concern" until the mid/late 2000s (Khoo 2011 p. 343) - although it should be noted that internationalism preceded internationalization (Pike 2012), including under the

\footnotetext{
${ }^{5}$ These figures are based on an analysis of point requirements for all courses across HEIs. A list of point requirements is available at www.careersportal.ie.

${ }^{6}$ In addition, the "international" criterion is where all four ranked universities score the highest; rankings constitute an incentive for internationalization in this regard also.

${ }^{7}$ Based on HEA figures (domiciliary origin of full-time students, 2014-2015). These exclude students based in Northern Ireland as well as part-time/one-term only students. UCD claims a higher percentage due to its overseas campuses.
} 
umbrella of developmental aid programs (detailed in Khoo 2011) and Irish universities have been sponsoring student mobility since the nineteenth century. ${ }^{8}$ All universities have now integrated internationalization in their respective strategic plans and adopted the vocabulary of "world-class" status (for the leading universities) or global ambitions (for the others). For TCD, enhancing its international profile goes hand in hand with reinforcing its elite status:

Trinity College Dublin's global reputation as a world-leading university is reflected in its standing in the world university rankings . . . Developing a global focus will raise the profile of Ireland's leading university as an international education destination and research hub. (TCD Global Relations Strategy) ${ }^{9}$

For the better positioned HEIs like TCD in Ireland, internationalization is "instrumental to prestige" (Seeber et al. 2016). For its part, UL has blended internationalization in its institutional image of a dynamic university engaged with enterprise and focused on graduate employability:

The University of Limerick has the largest and most successful Erasmus programme in Ireland with 1 in 3 undergraduate students spending a semester overseas on study or work placements . . . it is known that time spent abroad directly enhances students' employability, which is reflected in the fact that the University of Limerick has the highest graduate employment rate in Ireland. (Professor Paul McCutcheon, Vice President of UL) ${ }^{10}$

MU aims to double outgoing and incoming numbers in order to create "a truly intercultural and multilingual institution" (National University of Ireland Maynooth 2011, p. 25). Located $30 \mathrm{~km}$ from Dublin and its three universities, MU traditionally prided itself on student support and care rather than making claims to elite status; but recent developments ("re-branding" and investment in very significant campus development) seem to indicate a shift. Like the other younger universities, MU is no longer content with occupying a niche on a horizontal market. All HEIs are now competing for higher positions in a vertical status hierarchy, some with a view to competing globally.

All seven universities have gradually centralized and formalized their internationalizing strategies, in part by opening international offices through the 2000s. The level of investment varies, with UCD emerging as the most aggressive recruiter. Its international center is large and includes a "Global Lounge" for international students to socialize. Significantly, it employs 40 full-time staff, twelve of which are based in "UCD Global Centres" overseas. UCD is concentrating its efforts on recruiting from Northern America, China, India (four dedicated recruitment officers for each) and South-East Asia (three recruitment officers). Controversially, UCD has also decided to build a Confucius Institute on campus as part of its

${ }^{8}$ One example is the enduring "Travelling Studentships," largely based on academic criteria, offered by NUI (of which NUIG, UCD, MU and UCD are part) since its creation in 1908 (NUI 2008).

${ }^{9}$ www.tcd.ie/globalrelations/strategy/

${ }^{10}$ www.ul.ie/news-centre/news 
internationalization strategy. ${ }^{11}$ By contrast, the International Office of NUIG (which is half the size of UCD) employs 10 staff. The degree to which internationalization processes are centralized and formalized varies too, although overall the tendency is toward greater administrative and lesser faculty control. ${ }^{12}$ Typically, non-EU programs are managed exclusively by international office administrators, and academic coordinators recruit candidates for Erasmus mobility only. Similarly, new non-EU partnerships are often established by senior managers in line with institutional objectives, rather than by faculty.

\section{Strategic partnerships}

A more nuanced picture emerges from looking at international exchange in a qualitative rather than quantitative light. Ballatore and Blöss (2008) argue that partnerships are established within the Erasmus scheme according to "selective affinities" and reflect national status differences between institutions. Red-brick universities in the UK are thus more likely to be partnered with the newer, provincial French universities than the established ones.

In Figures 1 and 2, universities are ordered on the vertical axis according to their respective positions in the 2015 THE ranking. Figure 1 displays the proportion of UK partners in each rank bracket; and Figure 2 the proportion of non-EU partners in each rank bracket. Partners which are not ranked are counted in the "over 400" category. DCU is not included in Figure 1, as there was not enough information available on its UK partners. DIT is included instead and illustrates the sharp contrast between low-ranked universities and the highest ranked Institute of Technology.

\section{Figure 1. UK partnerships by rank bracket}

11 Confucius Institutes are Chinese cultural centers overseen by the Chinese government. Academics in Ireland have expressed concerns over the cost of the center as well as its governance structure, which they perceive as a potential threat to academic freedom.

${ }^{12}$ At the other end of the spectrum, the National College of Arts and Design has not set up a dedicated international center or hired additional staff for this purpose; exchange programmes are managed by administrators working closely with faculty. For this particular college, capacity is a challenge, and incoming and outgoing flows must be strictly balanced, which limits the scope for international recruitment; the small size and professional orientation of courses additionally help to explain the high level of faculty engagement. 


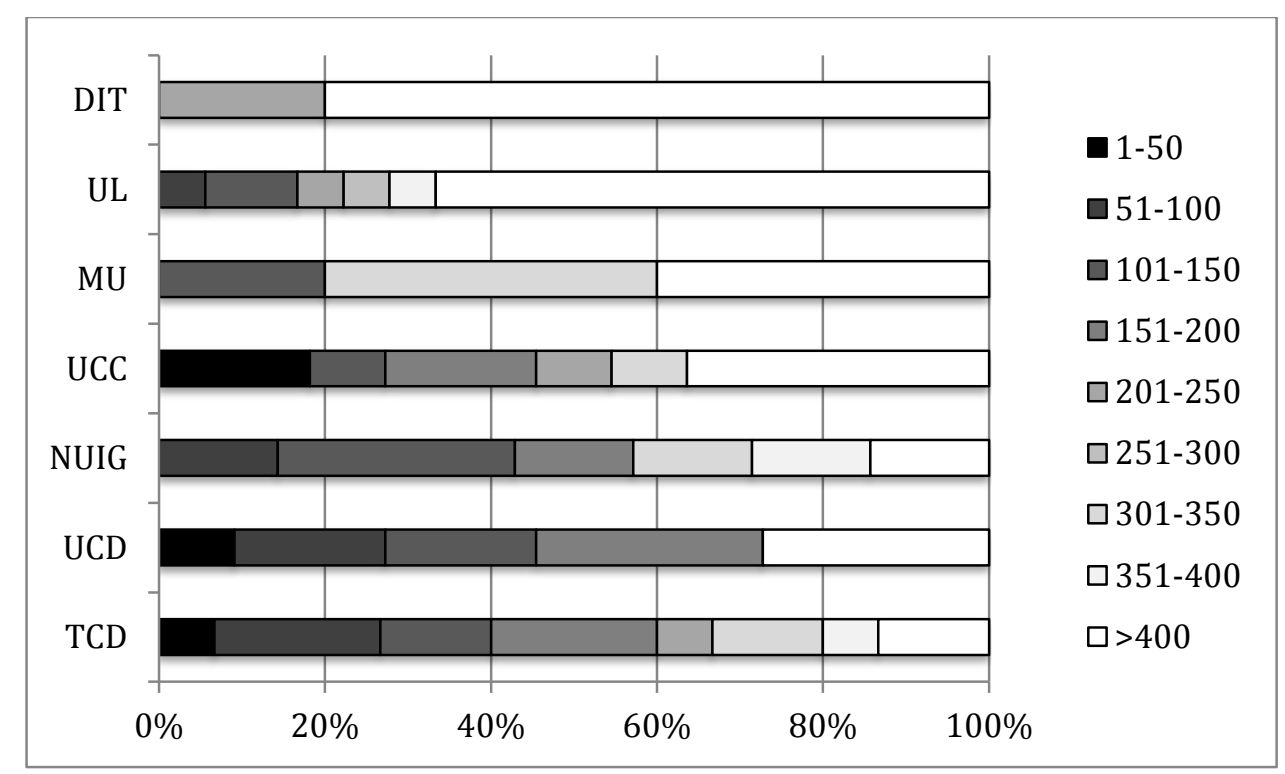

Figure 1 shows that the better ranked Irish HEIs are more likely to secure agreements with well ranked British universities. In addition, a number of UK partners are ranked above their Irish partner university. For instance, TCD has six UK partners ranked higher than its own position at 138. This is particularly significant in the case of the UK, where there is little appetite for Erasmus in Ireland but high demand among Irish students for UK places: flows are imbalanced in favor of the UK, and the Irish universities are in a subordinate position in these particular relationships. A similar pattern emerges from an examination of non-EU partnerships, as Figure 2 (which includes all seven universities) illustrates.

Figure 2. Non-EU partnerships by rank bracket

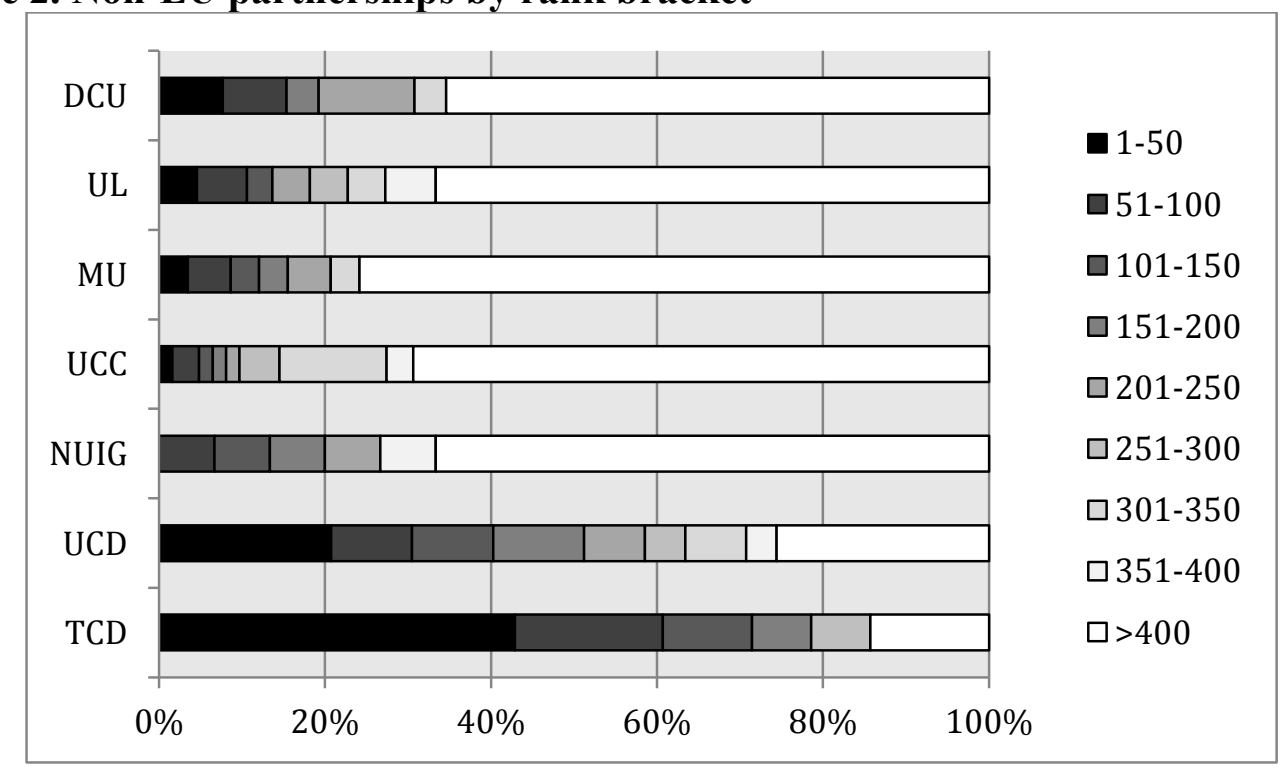

TCD again emerges as the university with the highest proportion of highly ranked partners. Over 60 percent of the partners of the other five universities are unranked.

These details are based on lists of partners as displayed by the universities. Some partnerships may be inactive, unbalanced or involve only a small number of places; these do not reflect actual student flows. In addition, new partnerships are negotiated all the time. But the rationale for initiating and maintaining partnerships is 
not solely based on numbers; in fact, choices are also influenced by the prestige of the partner university:

China is probably our biggest [partner] but then again the links we have in China, one or two of them would be quite prestigious universities, so we kind of see it as - even though we're not sending [students to them], they're good to have as partners. (S., International coordinator, new university)

The lists of partners displayed by the universities thus speak to the image each HEI seeks to present. Partnerships with elite colleges suggest that the Irish institution is on a par with its prestigious partners.

Out of a total of 210 university-wide partnerships across the seven universities, 137 are with universities in Canada, the USA, Australia and New Zealand. That compares to 82 with universities across Asia and South America; one with Russia; and none with Africa or the Middle East. While partnerships with elite institutions in the English-speaking world may enhance the profile of individual HEIs, these institutional strategies depart from the focus advocated by the government on the high-growth economies and identified future trade partners of South America and Asia. In terms of student flows, this is compensated for by one-way partnerships but not reflected in visible reciprocal agreements. For instance, incoming numbers from Africa and the Middle East are high (16 percent of the non-EU intake),${ }^{13}$ but Irish universities have not established university-wide partnerships in these regions.

This suggests that Irish institutions, and TCD and UCD in particular, are striving to become members of the world-class group of universities, which is essentially a Western model (Deem et al. 2008). The unequal relationship between world regions thus remains unchallenged. The logics of financial profit (drawing wealthy students from developing countries with low capacity for higher education such as China and countries in Africa), economic globalization (partnerships with high-growth economies in China, South-East Asia or South America) and institutional prestige (partnerships with UK/US elite colleges) overlap but are not completely aligned. In this respect, TCD for instance favors institutional prestige, while UCD is more engaged with the long-term economic and political mission assigned to the sector by the government. On a side note, this also confirms the hegemonic position of elite US and UK universities in the global higher education field, as well as the porous boundaries between the national and the global fields (Marginson 2006).

\section{Differentiation within universities}

As already illustrated, not all partnerships are equally valued. In particular, there is a difference in status between Erasmus and other (non-EU) exchanges. Overall, Erasmus flows between Ireland and the rest of Europe are imbalanced in favor of Ireland (6277 incoming and 2762 outgoing students in 2012-13), but this apparent advantage is in fact problematic for HEIs. When a university receives more students than it sends out, the partnership is not financially viable for the receiving university, which is required to provide education to non-contributing students. Students still spend money in Ireland and would be considered beneficial from a national policy

${ }^{13}$ Based on HEA domiciliary origin figures for 2013-2014. 
perspective, but at HEI level they put increased pressure on capacity and resources. The problem is more acute for HEIs drawing students from lower socioeconomic backgrounds, as the cost barrier is a significant deterrent for outgoing mobility.

Given the demand for English-language immersion and the relatively low numbers of Irish students studying European languages, Irish universities are in a strong position to negotiate the Erasmus partnership game with countries other than the UK. International officers review their international agreements regularly and, when the case arises, either reduce the number of places or terminate the partnership:

We tend to receive more than we send out, and that's something that we need to be aware of . . . the balance has to be monitored on a yearly basis, and I mean we're not too strict . . . clearly if we have a situation where only four students are choosing Italian as their language, there's no point in having like 18 places, because we'll get 18 students from Italy. (E., international coordinator, old university)

They're sending students here all the time and we just can't get ours to go, so the imbalance grows every year and it's costing us money. (S., international officer, new university)

By contrast, UK partnerships are highly valued. International officers in two new universities commented that it was difficult to maintain these partnerships or to secure new ones.

The difference in status between Erasmus and non-EU programs is sometimes apparent from the allocation of floor space and staffing levels of International Offices, with very small numbers of full-time positions dedicated to Erasmus compared to non-EU recruitment or exchange. According to this international officer, such distinctions have financial motives:

They need the revenue and international students bring revenue . . . the EU students don't bring fees, so there's an element there of - you know, well, the international dimension of the campus, but then there's the revenue these students are bringing to the university and that's needed as well. So that's kind of - you know, they're bringing quite a lot of money as well. (E., international coordinator, old university)

Erasmus students are beneficial to the "international dimension of the campus," but the "international students" (understood here as non-EU) add an international dimension and bring in revenue. The hierarchy of students involved in these different types of schemes is also visible in the services afforded to them, for example orientation trips and free access to campus sport services among others. In separate interviews, two international officers complained, off the record, about attitudes toward (incoming and outgoing) Erasmus students. One in particular felt the Erasmus students were treated as "second-class citizens" compared with students involved in non-EU exchanges. Another explained that he resented being asked to increase outgoing Erasmus numbers to make space on campus for fee-paying non-EU students. While this speaks to the differential status of these two types of exchange, and makes explicit the role of outgoing mobility in quite literally making space for incoming feepaying students, it also highlights the disconnect between institutional strategies and the reality as mediated by agents who value care over financial logics. This was 
articulated by M., Erasmus coordinator at a "new" university: "I don't care if the president doesn't care about Erasmus students. We still look after them."

These status differences are also visible in academic requirements and more generally in the recruitment process for the various strands of exchange. Applications for non-EU exchange have to be submitted earlier in the academic year and are often vetted by the students' lecturers. They typically require academic transcripts and a statement of interest. As mentioned by an academic coordinator, with some uneasiness, only "elite" students are sent to "elite" partner institutions:

Toronto is only $1^{\text {st }}$ class honours ... We wouldn't send a student who is - because it's so prestigious, we wouldn't send a student who is just pass or you know, it doesn't look good [AC: From what point of view?] Like for us to be sending students that are not elite students, you know [AC: Would it be a problem for the host university?] I can't imagine they would accept them; fees there are 10,000 a year; it's a university for elite students. (A., international officer, new university)

By contrast, the imbalance in flows means that it is relatively easy to secure a place on an Erasmus exchange. In the same university, places are allocated on a first-come first-served basis, and students generally get the destination they want (provided it is not the UK). In another university, an academic coordinator explained that each year he ranked student applications by grade and advised students with low grades not to apply. However, most of the selected applicants dropped out, and he ultimately had to accept all applications and even "beg" students to take part. In this case, it was as if there had been no academic selection.

International partnerships may be "university-wide" or established specifically for one or more faculties, as a result of which the offer varies from one faculty to another. Even when a program is designated as being university-wide, in effect students from certain faculties may be prioritized (as several arts students I interviewed found out at their expense; one, for instance, commented that "they were mainly interested in things like engineering students and finance students"). Business or law students can generally avail themselves of additional options, as their departments develop their own partnerships with business and management schools abroad, sometimes independently of the central International Office. One coordinator explained that the ranking of the partner university was extremely important in his decisions to set up new partnerships; another, tasked with setting up exchanges principally for arts students, focused instead on the environment and support offered by potential partners.

Compulsory exchange is more likely to be a feature of select business courses with a language element. Language students are generally also strongly encouraged to go abroad. For students of other faculties, it is usually entirely voluntary and takes the shape of either a term abroad in lieu of a term at home, or an additional year assessed only on a pass/fail basis (which again devalues the exchange from an academic perspective). But whether a year abroad is built into a program or not does not necessarily indicate higher status. One of the new universities has thus recently launched an innovative strategy that makes exchange compulsory on many courses. It has allowed the university to achieve a balance between incoming and outgoing student flows. The compulsory term abroad was first rolled out in the arts and social science faculties - subordinate disciplines - and extends to all students, regardless of their academic level and motivation (or lack thereof). This enforced "massification" 
of Erasmus has put pressure on the International Office to secure partnerships in lesser-known colleges in Eastern European countries, where courses may be taught in English and the cost of living is cheaper for students. These are much less prestigious destinations. In addition, the relative lack of resources makes it difficult for administrators (and academics) to monitor the quality offered by these new partners or provide much-needed support. In this case, competing logics are at play, which ultimately are constrained by the inferior position of the institution in both the national and international fields.

\section{Conclusion}

The internationalization of higher education is focused at national policy level on increasing revenue and supporting Ireland's position in the global economy. The Irish state takes an active role in driving internationalization by setting financial incentives and helping HEIs materially to penetrate target markets, but at the same time it is reducing funding to the sector and placing other, competing demands on HEIs. All HEIs have embedded internationalization in their strategic plans, and world-class status (for the more established ones) or ambitions (for the challengers) in their institutional identities. But HEIs have to manage multiple constraints, which include funding and capacity issues, international market forces, and the secondary position of Ireland in the global higher education market. Market forces, and congruent government intervention, produce a significant level of isomorphism across the sector in terms of guiding principles and broad patterns of commercially focused internationalizing activities.

However, while all Irish HEIs operate in the same national policy environment and face similar pressures, their ability to respond to and harness internationalization varies in a way that is consistent with allomorphism rather than isomorphism (Vaira 2004). The higher education sector is small but stratified, with universities occupying different positions in the national field. These positions translate into different demographics and varying levels of income, with universities at the top better able to attract higher proportions of postgraduate and non-EU students, who pay higher fees than local undergraduates. Although relatively unknown compared to their English counterparts, well-established universities have a broader repertoire of selling points and more resources to invest in marketing initiatives. These institutions are better able to secure prestigious international partners. In this sense, internationalization is not a game-changer as far as configuration of the national field of higher education is concerned. Rather, it brings out the otherwise subtle stratification within the field and may reinforce the ongoing differentiation of HEIs.

Both between and within HEIs, exchange destinations are becoming increasingly stratified in a way that mirrors pre-existing hierarchies. Financial logics dictate the resources allocated to the different types of programs on offer. Official university-wide bilateral exchange agreements reveal more complex logics, where institutional prestige, financial considerations and alignment with national trade goals compete. HEIs at the higher end of the status hierarchy favor high-status, strategically located partners, and TCD in particular seems intent on positioning itself on an international world-class market, while other institutions are not in a position to deploy strategies of distinction to the same extent. Closer study of university partnerships, student flows and the various approaches to outgoing mobility thus 
reveals the differentiation emerging from the interplay between isomorphic forces on the one hand and organizational identities and field positions on the other.

\section{References}

Altbach, P. (2007). Tradition and Transition: The International Imperative in Higher Education. Boston, MA: CIHE, Boston College.

Ball, S. J. (2012). Global Education Inc.: New Policy Networks and the Neoliberal Imaginary. London and New York: Routledge.

Ballatore, M. and Blöss, T. (2008). Le sens caché de la mobilité des étudiants Erasmus [The hidden meaning of the mobility of Erasmus students] in F. Dervin and M. Byram (eds), Échanges et mobilités académiques: Quel bilan? Paris:

L'Harmattan, pp. 17-42.

Bartell, M. (2003). Internationalisation of Universities: A University Culturebased Framework. Higher Education, 45, pp. 43-70.

Bourdieu, P. (1996). The State Nobility: Elite Schools in the Field of Power. Cambridge: Polity Press.

Cantwell, B. and Maldonado-Maldonado, A. (2009). Four Stories: Confronting Contemporary Ideas about Globalisation and Internationalisation in Higher Education. Globalisation, Societies and Education, 7(3), pp. 289-306.

Clancy, P. (2015). Irish Higher Education: A Comparative Perspective. Dublin: Institute of Public Administration.

Courtois, A. (forthcoming). Elite Education and Social Inequality: Privilege and Power in Ireland's Top Private Schools. Basingstoke: Palgrave Macmillan.

Courtois, A. and O'Keefe, T. (2015). Precarity in the Ivory Cage:

Neoliberalism and Casualisation of Work in the Irish Higher Education Sector. Journal of Critical Policy Studies, 13(1), pp. 43-66.

Currie, J., Deangelis, R., de Boer, H., Huisman, J., and Lacotte, C. (2003). Globalizing Practices and University Responses: European and Anglo-American Differences. Westport: Greenwood Publishing Group.

Deem, R., Mok, H. K. and Lucas, L. (2008). Transforming Higher Education in Whose Image? Exploring the Concept of the 'World-Class' University in Europe and Asia. Higher Education Policy, 21, pp. 83-97.

DES, Department of Education and Skills (2010). Investing in Global Relationships. Ireland's International Education Strategy 2010-15. Dublin: Department of Education and Skills.

DiMaggio, P. and Powell, W. (1983). The Iron Cage Revisited: Institutional Isomorphism and Collective Rationality in Organizational Fields. American Sociological Review, 48(2), pp. 147-160.

Enders, J. (2004). Higher Education, Internationalisation, and the Nation-state: Recent Developments and Challenges to Governance Theory. Higher Education, 47, pp. 361-382.

Education in Ireland (2012). International Students in Higher Education in Ireland 2011/12. Dublin: Education in Ireland.

Fligstein, N. and McAdam, D. (2012). A Theory of Fields. Oxford: Oxford University Press.

Foskett, N. (2010). Global Markets, National Challenges, Local Strategies: The Strategic Challenges of Internationalization. In N. Foskett and F. Maringe (eds.) 
Globalization and Internationalization in Higher Education: Theoretical, Strategic and Management Perspectives. London, Continuum, pp. 35-40.

Harkin, S. Hazelkorn, E. (2014). Restructuring Irish Higher Education through Collaboration and Merger. In A. Curaj, L. Georghiou, J. Casingena Harper, R. Pricopie and E. Egron-Polak (eds.) Mergers and Alliances in Higher Education: International Practice and Emerging Opportunities. Dordrecht: Springer.

Hazelkorn, E. (2015). Rankings and the Reshaping of Higher Education: The Battle for World-Class Excellence. Second Edition. Basingstoke: Palgrave Macmillan. HEA, Higher Education Authority (2012). Key Facts and Figures: Higher Education 2011-2012. Dublin: HEA

HEA, Higher Education Authority (2014). Higher Education System performance Framework 2014-2016. Dublin: HEA.

Hunt (2011). National Strategy for Higher Education to 2030 - Report of the Strategy Group. Dublin: HEA.

Khoo S.-M. (2011). Ethical Globalisation or Privileged Internationalisation?

Exploring Global Citizenship and Internationalisation in Irish and Canadian Universities. Globalisation, Societies and Education, 9(3-4), pp. 337-353.

IUA, Irish University Association (2014). 'Higher Education in Ireland:

Performance and Sustainability', infographic. http://www.iua.ie/wpcontent/uploads/2014/10/IUA-Infographic-Sept-2014.jpg

Lynch, K. (2013). New Managerialism, Neoliberalism and Rankings. Ethics in Science and Environmental Politics, 13, pp. 141-153.

Marginson, S. (2006). Dynamics of National and Global Competition in Higher Education. Higher Education, 52(1), pp. 1-39.

Marginson, S. (2013). The Impossibility of Capitalist Markets in Higher Education. Journal of Education Policy, 28(3).

Matus, C. and Talburt, S. (2009). Spatial Imaginaries: Universities, Internationalisation and Feminist Geographies. Discourse: Studies in the Cultural Politics of Education, 30(4), pp. 515-527.

McCoy, S. and Smyth, E. (2011). Higher Education Expansion and Differentiation in the Republic of Ireland. Higher Education, 61, pp. 243-260.

Mosneaga, A. and Agergaad, J. (2012). Agents of Internationalisation? Danish Universities' Practices for Attracting International Students. Globalisation, Societies and Education, 10(4), pp. 519-538.

National University of Ireland Maynooth (2011). Strategic Plan 2012-2017. Maynooth: National University of Ireland Maynooth.

Paradeise, C. and Thoenig, J.-C. (2015). In Search of Academic Quality. Basingstoke: Palgrave Macmillan.

Pike, G. (2012). From Internationalism to Internationalisation: The Illusion of a Global Community in Higher Education. Journal of Social Science Education, 11(3), pp. 135-149.

Popp Berman, E. and Paradeise, C. (2016). Introduction: The University under Pressure. Research in the Sociology of Organizations, 46, pp. 1-22.

Rivzi, F.; and Lingard, B. (2010). Globalizing Education Policy. Abingdon: Routledge.

Salmi, J. (2009). The Challenge of Establishing World-class Universities.

Washington: World Bank Publications.

Seeber, M.; Cattaneo, M.; Huisman, J. and Paleari, S. (2016). Why do Higher Education Institutions internationalize? An Investigation of the Multilevel 
Determinants of Internationalization Rationales. Higher Education, advance online publication.

Stensaker, B., Frølich, N., Gornitzka, Å., and Maassen, P. (2008).

Internationalisation of Higher Education: The Gap between National Policy-making and Institutional Needs. Globalisation, Societies and Education, 6(1), pp. 1-11.

Tannock, S. (2009). Global Meritocracy, Nationalism and the Question of Whom we Must Treat Equally for Educational Opportunity to be Equal. Critical Studies in Education, 50(2), pp. 201-211.

Teichler, U. (2002/3). Diversification de l'enseignement supérieur et profil individuel des établissements [Diversification of Higher Education and Individual Profile of Institutions]. Politique et gestion de l'enseignement supérieur, 14, pp. 199212.

Vaira, M. (2004). Globalization and Higher Education Organizational Change: A Framework for Analysis. Higher Education, 48, pp. 483-510.

University of Limerick (2010). Pioneering and Connected: Strategic Plan 2010-2015. Limerick: University of Limerick. 